\title{
Belarusian Foreign Policy in the Middle East: A Neorealist Model of Relations between Belarus and Iran
}

\author{
BY \\ SIARHEI BOHDAN*
}

Relations between Belarus and Iran have stirred up controversies concerning their alleged anti-American character. Yet, the Belarusian leadership has avoided making serious anti-American gestures with Tehran doing its best to alleviate Western concerns in this regard. The chosen course of relations has demonstrated the limits of defiance to the international system. Both Minsk and Tehran cannot ignore the counteractions of their opponents, especially the United States, to this cooperation. With the emergence of a unipolar world, changes in global international structures and the rising influence of the United States have all defined the general dynamics of Belarus-Iranian relations. Domestic factors, such as the state's own general capacities, have shaped this relationship considerably less.

Both Belarusian and foreign media for nearly two past decades have regularly discussed Belarusian relations with Iran. The issue, however, remains almost entirely in the realm of the mass media and political polemics. Students of Belarusian foreign policy have so far failed to seriously analyse the countries links with Iran. Most state-affiliated analysts and media in Belarus often articulate issues related to relations with Iran, pointing out the need to diversify Belarus' foreign partners.

Analysts and media critical of the government's policy mostly argue that the Belarusian leadership follows a set of ideological preferences (left and/or anti-American) in dealing with developing countries in general and with Iran in particular. Arguing in this vein they essentially follow liberal theories of international relations. These prefer domestic factors (for example, the political regime of a country) in explaining the foreign policy behaviour of the government.

\footnotetext{
* Siarhei Bohdan is a Senior Analyst with the Ostrogorski Centre and a $\mathrm{PhD}$ candidate at Freie Universität Berlin.
} 
This article aims to propose a contrary, neorealist model to explain Belarus' relationship with Iran. Neorealism (or structural realism) and theoretical schools closely related to it emphasise external factors, like the structure of the international system in their analysis of international relations. Several reasons implicitly point to (neo)realism serving as a promising model to analyse Belarusian foreign policy towards Iran, solidifying it as a case study of Belarusian foreign policy towards other developing nations.

First, liberal theories fail to explain the essential feature of Belarusian foreign policy in the developing world, namely its opportunism. Belarus shifted its priorities in the Middle East from Iraq to its opponents Iran and Syria already back in early the 2000s. The Belarusian government shifted its focus further to Iran's foes, such as the Arab monarchies of the Persian Gulf in the late 2000s and early 2010s. Moreover, Minsk has managed to maintain relations with nations that are in confrontation with each other (like Iran and Israel) at the same time. With only formal contacts involving left-wing Belarusian leadership has demonstrated no ideological sympathy toward many left-wing anti-Western governments. Thus, contact with radical regimes in Bolivia and Ecuador has remained at a minimal level for years. There were only formal contacts with left-wing governments in Argentina and Brazil. Minsk had even less interest in the construction of ideologically-motivated blocs effectively ignoring a tripartite union with Venezuela and Syria, as proposed by the late Venezuelan president Hugo Chavez in 2010.

Second, Belarusian officials themselves discuss international relations in terms that approximate with (neo)realist concepts, although in cruder forms. The then head of the Presidential Administration and current Foreign Minister Uladzimir Makiej proclaimed 'the Law of the Jungle - everybody for themselves - is effectively prevailing in the world...the rule of strongest...the stronger has the right to rule and imposes his will' (Belapan 2011). Statements like these suggest that the Belarusian ruling elite are employing a logic that is close to the (neo)realist approach, as they analyse foreign policy choices and make decisions on them..

In the same vein, Belarusian leader Aliaksandr Lukašenka said:

military force unfortunately remains in the armoury of means used to solve international $[. .$.$] problems. [...] These difficult circumstanc-$ es oblige us to look after our security, sovereignty and independence by relying, first of all, on our own forces. Belarus has no geopolitical ambitions, but we will defend our national interests by all available means (Web site of President of Republic of Belarus 2013a).

Thus when the regime seeks alliances internationally, the government should follow the logic of survival rather than ideological preferences. 
On another occasion, Lukašenka pronounced with more clarity the postulates of (neo)realism, 'The USSR was a counterbalance, it provided multipolarity in the world. Now, we are looking for this multipolarity. But it is very difficult to achieve it nowadays. Hence [we see] tensions...' (Web site of President of Republic of Belarus 2013b). As these statements show, in fact realism became a paradigm that is shaping Belarusian foreign policy.

Still, neorealist theory requires further examination against the facts of the relationship between Belarus and Iran. To afford this relationship the critical examination it requires, this article consists of three parts. The first part reviews neorealism as a theory and sorts through its basic assumptions and concepts, determining which are the most relevant in regards to Belarus-Iranian relations. The second part reviews in detail the course of relations between Belarus and Iran from a neorealist perspective, identifying stages of cooperation and the content of these interactions. The third part discusses what the neorealist approach explains about the relationship between Belarus and Iran. The primary concern of this article is why these relations started, developed, flourished and declined. The conclusion summarises the answers uncovered, attempting to place them in the general context of Belarusian foreign policy.

\section{Theoretical Foundation: Is There a Place for International Cooperation in Neorealism?}

\section{Neorealist View of International Cooperation}

Neorealism emphasises that the structure of international politics defines the general contours of international politics and the foreign policies of individual states. After the end of the Cold War and the end of a bipolar world, the conditions of international politics have fundamentally changed. In the Cold War all relatively important political events were positioned in relation to global the AmericanSoviet confrontation. This confrontation created some additional chances for minor players. The two superpowers could not put too much pressure on them for fear they could desert to the other superpower. The smooth changing of sides demonstrated by countries like Iraq or Egypt illustrates this point.

After the Cold War minor international players had effectively no serious defender to go to if they had conflict with the sole superpower (America). Of course, the transformation of the bipolar world took years, and Saddam's Iraq until the early 2000s tried the old tactics of counterbalancing Western pressure by turning to Russia. Yet Russia could not deliver and it ended badly for Saddam whose regime's fall clarified to the world that the bipolar world order had disappeared. 
The circumstances of a unipolar world radically limited opportunities to challenge the dominant international power. Yet defiance and challenge still occurs, giving rise to specific kinds of international cooperation between opponents of the West in a hostile international environment. Structural realism is sceptical about the prospects of international cooperation. However, its concept of relative gains, specified below explains the cooperation between Belarus and Iran since the 1990s. Next, we shall consider conditions, results and consequences of cooperation in the wider international context.

Initial discussions in academic literature on the subject of relative gains, analysed the distribution of gains between cooperating partners. If a state sees its absolute gains as larger than the gain acquired by its partner(s), it considers the balance of power as shifting in its favour and so embarks on a course of cooperation (Waltz 1979, 105). As Grieco argues:

'realists find that states are positional, not atomistic, in character, and therefore realists argue that, in addition to concerns about cheating, states in cooperative arrangements also worry that their partners might gain more from cooperation than they do' $(1988,497)$.

However, as Niklas Schörnig notes:

Waltz and Grieco fail to consider that every absolute gain also means a relative gain vis-a-vis the states not involved in cooperation, so that it is only very difficult to assess the net effect of a gain resulting from the cooperation $(2006,88)$.

This means that cooperation is an interaction, which involves not only immediate cooperative partners, but also the broader international state environment, which might be affected by results of said cooperation and its consequences.

In sum, for countries vulnerable to outside pressure (like Belarus), an international constellation, balance of forces, probability of punishments for defiance to norms and sanctions set by dominant world powers, play a crucial role in defining the limits of possibility in Belarus' foreign policy. The government has to weigh relative gains against attendant potential risks and cannot compartmentalise relations with different nations.

The concept of relative gains, however, contains some inconsistencies. As Grieco argues:

'according to realists, states worry that today's friend may be tomorrow's enemy in war, and fear that achievements of joint gains that advantage a friend in the present might produce a more dangerous potential foe in the future' $(1988,487)$. 
But, what if there are no reasonable grounds to conceive the existence of such a potential danger stemming from another state, even in the foreseeable future?

Grieco also says:

'driven by an intense interest in survival, states are acutely sensitive to any erosion of their relative capabilities, which are the ultimate basis for their security and independence in an anarchical, self-help international context' $(1988,498)$.

Here the important omission is the undefined meaning of 'relative', namely, relative to whom?

An even more nuanced solution to the problem that some states have an unequal importance in national security calculations of a particular state is provided by the concept of positionality. Waltz suggests 'the first concern of states is not to maximize power but to maintain their position in the system' $(1979,126)$. Of course, this statement contains ambiguities as well. He fails to specify which system he means and this system is likely not singular in nature, but rather one made up of many different components (regional subsystems).

The assumption that the international system has its own structure has been (in general terms) discussed by Schweller (1998). He insists that the neorealist division between bipolar and multipolar systems often proves inefficient, as analytical approaches taking a careful look at the distribution of power, may unveil foreign policy effects that the systemic structure can predictably produce. According to him, relative power influences national policies. The structure of the international system (the distribution of material power capabilities) has critical impact on alliance formation and foreign policies.

Refinement of the notion of relative gains enables us to more efficiently analyse international cooperation from a neorealist perspective. This refinement through considering relative gains in a wider context integrates the notion of international cooperation within the structure of the international system. International cooperation in a given political circumstance may lead to so called balancing alliances.

\section{Balancing Alliances: Neutralizing Russian/Western Hegemony?}

Neorealism insists on the absence of hierarchy among states. However, it does not mean that for every country all others are equally relevant in terms of their national security interests. Both the geographical location and the geopolitical constellation make various nations more or less relevant in national security terms for any given state. Countries cooperate and ally themselves with other states that 
do not possess serious offensive potential in relation to them. The resulting alliance is a major tool to improve one state's standing in global politics.

Mearsheimer ${ }^{1}$ discusses the possibility of balancing alliances aimed at 'containing an aspiring regional hegemon' (2011, 31). Essentially, that concept is also a particular case of international cooperation. Such an alliance is an interaction aimed at getting relative gains in relation to a third country or countries. Although he discusses this specifically regarding possible United States alliance with Asian nations to contain Chinese regional hegemony, there is no reason to restrict such possibilities to a specific case.

Moreover, it is entirely logical to assume that the emergence of balancing alliances may take place not only to prevent or contain regional hegemons, but also to counteract global hegemony in general, or attempts by a nation to attain global hegemony by subduing and taking control of certain regions.

\section{Growing Power Generating Bigger Ambitions}

The bilateral relations between Belarus and Iran developed, inter alia, depending on the capacities of Belarusian and Iranian states. Gilpin explains that states are continually:

tempted to try to increase [their] control over the environment. ... A more wealthy and more powerful state ... will select a larger bundle of security and welfare goals than a less wealthy and less powerful state (1981, 22-23 and 94-95).

Growing power per se is an important phenomenon affecting corresponding changes in a state's national security and foreign policy. Leffler studied United States foreign policy in the initial stages of the Cold War, as the relative power of the state was increasing. He argued that a change in one's capabilities played a role in shaping policymakers' perceptions of threats, interests and opportunities (1992). According to Leffler, the policies implemented by the Truman Administration, although shaped by concern about the Soviet threat, were shaped by rising American might as well (1992). Moreover, he noted that United States policymakers worried primarily not about an immediate military threat, but rather potential future challenges to the broader international environment of the country. This idea was clearly set out by Fareed Zakaria, who exclaimed 'why, as states grow increasingly wealthy, do they build large armies, entangle themselves in politics beyond their

\footnotetext{
Although John Mearsheimer is usually classified as the founder of offensive realism school in international relations, his ideas used in this article essentially do not contradict main tenets of structural realism. Therefore, this article avoids discussion of distinctions between essentially neorealistic theoreticians and schools. The same is valid for Fareed Zakaria.
} 
borders, and seek international influence' $(1998,3) .{ }^{2}$ He argued that this stance follows the aspiration of states to control their environment. Wohlforth formulated it more rigidly saying that 'state behaviour [is an] adaptation to external constraints conditioned by changes in relative power' $(1995,8)$.

\section{The Black Box of the State: Domestic Factors in Neorealist Approach}

Aaron Friedberg (1988) and Melvyn Leffler (1992) developed so-called neoclassical realism by including domestic political factors in their studies. Friedberg emphasises, 'even if one acknowledges that structures [...] are important, there is still the question of how statesmen grasp their contours from the inside, so to speak' $(1988,8)$. He discovered that British officials during the period of the British Empire's decline 'simply ignored or papered over serious underlying weaknesses in Britain's position or, in solving certain problems, created new and perhaps more dangerous ones'. Friedberg argues that to understand such behaviour there should not only be shifts in relative power, but also organisational, intellectual and internal political conditions (1988, 295 and 290-91). Assessments of relative power by policymakers 'are related to, but not directly determined by, reality' and 'in turn, related to, but not fully determinative of, policy.'

Fareed Zakaria introduced a new variable related to domestic politics: 'strength of a country's state apparatus and its relation to the surrounding society' (1998, 11-12). This is a reference to the resources the national government can mobilise and dispose of. One of the factors influencing the amount of resources which can be mobilised is the existence of a state apparatus. Another is the level of resources used to defend against vital threats.

When talking about domestic factors in foreign policy-making, one cannot ignore ideology. Ideologies, seemingly, influence both perceptions and political decision-making and hence can contribute to shaping foreign policy priorities. Even committed proponents of political realism, like Carr pointed out the role of ideology (2001, 87 and 104-05). Although he proclaimed that states have a permanent appetite for power and 'the exercise of power always appears to beget the appetite for more power', he also emphasises that international politics is something more than just the pursuit of power 'pure realism can offer nothing but a naked struggle for power'.

Carr also argued that politicians and intellectuals follow not only power, but also ideals: 'utopia and reality [are] the two facets of political science; and therefore any sound political thought must be based on elements of both utopia and reality' (2001, 10 and 87). He concludes that 'this constant interaction of irreconcilable 
forces is the stuff of politics $(2001,88)$. Every political situation contains mutually incompatible elements of utopia and reality, of morality and power'.

Yet, Mearsheimer believes that:

Carr overstates the conflict between the pursuit of power and ideals. After all, states sometimes can pursue these two goals simultaneously. [...] In both cases [US vs. Germany in 1940s and United States against SU in early Cold War times], the United States was engaged in a just conflict that also made eminently good strategic sense, and so it did not have to choose between its ideals and its concerns about power $(2005,142)$.

In sum, the proposed neorealist model of Belarus-Iranian relations essentially relies on a vision of interaction between the two states in a broader context, determined by relative gains both countries hope to get (and got) at different stages of interaction. Both countries cooperate in order to compensate (at least partly) for their problems in relations with other countries. The balance of power in the international system makes them seek such cooperation while the growth of their power enables them to strive for new larger foreign policy and national security aims. The promotion of each state's foreign policy and national security interests, however, also depends on their internal capacities.

\section{Belarusian Relations with Iran - From Rise to Decline}

\section{State of the Art: What Scholars Write about Belarus - Iranian Cooperation}

Researchers have analysed Belarusian foreign policy towards developing countries only through its general traits (for instance, Ulakhovich 2009). Certainly some scholarly and analytical publications on Belarusian foreign policy towards Iran exist, yet the analytical publications identified thus far are either descriptive (Bohdan 2012), or very short comprising of a compilation of information (Bojarczyk 2009; Czachor 2011, 208-11).

Even less is written on Iranian foreign policy towards Belarus. Scholars usually disregard it (an example is Arjomand 2009). This is true even for specialised monographs on Iranian foreign policy published in the West (Takeyh 2009) and Iran (Azghandi 1388; Dehghani Firouzabadi 1389). Shireen Hunter, in her monograph on Ahmadinejad's foreign policy, dedicated only a few sentences to Belarus-Iran relations (2010).

The scarcity in volume of analytical and scholarly publications corresponds to the superficiality of their insights. So far, scholars have failed to put forth even 
minimally sophisticated political science models to explain these policies and Belarus-Iranian relations in the 1990s and 2010s.

\section{Origins, 1993-1996}

Belarusian relations with Iran started in 1993 and were apparently initiated by Tehran. In those years, Iran achieved its first success in overcoming the negative consequences from its war with Iraq, a war which ended in open military clashes with the United States. Under President Rafsanjani (1989-1997), Iran entered the so called Epoch of Reconstruction and expanded its economic and security interests (paying special attention to the latter due to the unstable situation on the borders and in some provinces of the country). The Iranian government tried both to tap opportunities generated by the collapse of the Soviet Union and to open up to some Western countries. Tehran, however, did not want to antagonise Moscow and acted with remarkable caution in the post-Soviet space. Iranian politics preserved the idea of post-Soviet nations as a domain of Russia even in the 2000s. The statements made in 2005 by the Iranian Chairman of Parliament Haddad-Adel and by the Iranian ambassador (2008-2012) to Belarus Abdollah Hosseini in 2010 are cases in point (FARS 2005). According to Hosseini, 'its [Belarus'] interests have become so intertwined with Russia that it cannot easily divide its political structure from Russia's' (Otagh Bazargani 1388).

The Belarusian leadership in the early 1990s was interested in contacts in the Middle East, even involving military matters. Visits to the Arab monarchies in the Persian Gulf by Prime Minister Viačaslaŭ Kiebič demonstrate this (Kebich 2008). The Belarusian establishment, however, had to deal with other vital issues until 1997, like the adoption of a new constitution, election of a new president and parliament and the ensuing confrontation between the two. Therefore, Belarusian foreign policy remained inert, confined in two directions, a stronger post-Soviet one (primarily, Russia) and an increasingly weaker Western one. Moreover, the establishment of the Foreign Ministry of Belarus still continued. It did not have the material, human, or organisational capacity to deal with new partners, such as Iran, effectively.

The visit of Belarusian Prime Minister Michail Čyhir to Iran in March 1995 and the reciprocal visit by Iranian Vice President Hassan Habibi to Belarus in July 1995 became the first high-level official contact between the two countries. Habibi signed (in Minsk) a series of agreements on investment, trade and economic relations, culture, transportation, but also on military cooperation and the sale of weapons to Iran. In addition, Belarusian and Iranian officials held talks on the possibility of shipping Iranian oil to Belarus. Habibi's visit took place just after Moscow (under United States pressure) committed not to sign new arms contracts with Iran and halt other military technical cooperation with Tehran. 
Some experts (like Colonel Ivan Safronov of Russian Kommersant daily) spoke about the possibility of selling Russian weapons through Belarus. It was opined that Russia would muddy the path of sending weapons to Iran, making it impossible to identify where the arms acquired by Iranians came from (Kommersant 1995). Nevertheless, no evidence exists that Belarus ever gained profit from selling Russian weapons for Moscow. Two published Belarusian contracts on the sale of military parts to Iran showed no clear signs of Moscow's involvement (Feduta 2005, 410).

\section{Stagnation, 1997-2004}

Still, there was a fair way to go to stabilise relations between Belarus and Iran. In August 1996 Iranian Foreign Minister Ali Akbar Velayati paid a visit to Minsk and in October 1997 Belarusian Foreign Minister Ivan Antanovič returned the visit. By 1997-98, the situation in Belarus had radically changed after president Lukašenka consolidated his power. Concurrently, the government ran into diplomatic trouble with the West. The Belarusian government set new priorities with a 'multi-vector' foreign policy. President Lukašenka proclaimed the 'multi-vector' principle of foreign policy at the All-Belarusian People's Congress in October 1996 'given our geopolitical situation only a multi-vector balanced foreign policy can be efficient' (Brazovskaya 1996, 28).

Lukašenka himself actively visited developing nations to find new partners, going to Iran in March 1998, too. The Belarusian government by that time could pursue cooperation with Iran in a more efficient and systematic way, after it reorganised its Foreign Ministry in accordance with actual needs of the state. In 1998 the Belarusian government merged the Foreign Ministry with the Ministry of the Commonwealth of Independent States and Ministry of Foreign Economic Relations. In addition, Belarus opened a significant number of embassies and consulates in the developing world. Among these was an embassy in Tehran (established in 1997).

Iran, for its part, faced a new reality as well. The United States remained unconvinced by the pragmatic deals proposed by successive Iranian governments and continued a policy of dual containment, envisioning the isolation of both Iraq and Iran. In April 1995, President Clinton banned all United States economic relations with Iran (Litwak 2000, 67). Tehran faced setbacks in relations with European countries, in particular after the so-called Mykonos crisis. A severe blow was dealt to Tehran by the Russian government, who in 1995 signed a memorandum with the United States on the halting of all military cooperation with Iran, including the implementation of signed and launched projects. 
Tehran found a solution to this problem by turning to other post-Soviet nations who badly needed money. Ukraine was prized the most as it possessed a more or less complete technological basis for production of the goods that Iran wanted (e.g., aircrafts and engines). Iran especially sought military or dual-use products and saw Ukraine as a viable partner for these. Belarus mainly produced components of military equipment or some equipment installed on Russian, or Ukrainian-made platforms. It still had some spare equipment from the Soviet army, which was not needed by its own armed forces. In an attempt to have a channel to former Soviet states independent of Moscow, the Iranian embassy in Kyiv dealt with relations with Belarus until an Iranian embassy opened in Minsk in 2000.

The first tangible projects were agreed on in the late 1990s which involved military sales. In the 2000s, Belarus sold Iran three parties of tanks (eight T-72M1 in 2000, fourteen T-72M1 in 2001 and fifteen T-72M1 in 2002) (UN 2011). Tehran still demonstrated limited activity with Belarus in the late 1990s. The Iranian government hoped that the Iranian reformist movement led by the new president (Mohammad Khatami, 1997-2005) could find an opening to the West. Moreover, in 2001 Putin declared that Moscow would not adhere to agreements with the United States on halting military contracts with Iran. This gave new hope to Tehran, especially after Putin signed a series of new contracts with Iran.

After Iranian Defence Minister Admiral Shamkhani visited Moscow to sign new contracts in 2001, he briefly went to Minsk as well. Yet Tehran hardly displayed much interest in Belarus. A visit from the Belarusian president to Iran went unreturned for more than five years. Khatami declined to visit Minsk even as he visited neighbouring states.

\section{Rise, 2005-2009}

The situation in the mid-2000s changed once more, as Iranian attempts at rapprochement with the West again failed. Quarrels with the West over the Iranian nuclear program followed. The reformist parliament and president in Iran were replaced with a more radical parliament and president.

Since 2002 Belarus has faced ever harsher treatment by the Russian government. Minsk sought actively to diversify its foreign relations, especially after its regional manoeuvrability diminished as Central and Eastern European countries, including the Baltic States and Poland joined NATO and the EU. Thus ideas of regional security and cooperation mechanisms between Belarus and its neighbours were discarded. As a result, Belarusian relations with Iran flourished in the mid-tolate 2000s. In 2006, the leading Iranian car manufacturer, Iran Khodro, started assembly production of Iranian Samand cars in Belarus. The following year the 
Belarusian national oil company Belorusneft launched an oil extraction project in Iran. In 2010, MAZ started assembly production in Iran.

However, intensive contacts and political relations did not provide a corresponding increase in bilateral trade (see Table 1). In 1993 trade reached only $\$ 89,000$, in 2000 it improved to $\$ 25.9$ million, and in 2001 it jumped to $\$ 38.7$ million (Ministry of Foreign Affairs 2002). The Belarusian and Iranian presidents set a goal to achieve $\$ 100$ million in trade turnover by 2004 . However, this remained unaccomplished until 2010.

Table 1. Belarusian Trade with Iran, USD mln

\begin{tabular}{|l|c|c|c|c|}
\hline Year & Trade Turnover & Export & Import & Saldo \\
\hline 2003 & 21.4 & 20.5 & 0.9 & 19.6 \\
\hline 2004 & 36.7 & 33.3 & 3.4 & 29.9 \\
\hline 2005 & 38.4 & 35.6 & 2.8 & 32.8 \\
\hline 2006 & 35.6 & 31.7 & 3.9 & 27.8 \\
\hline 2007 & 75.9 & 66.5 & 9.4 & 57.1 \\
\hline 2008 & 93.8 & 83.6 & 10.2 & 73.4 \\
\hline 2009 & 71.6 & 63.2 & 8.4 & 54.8 \\
\hline 2010 & 104.8 & 97.2 & 7.6 & 89.6 \\
\hline 2011 & 138.7 & 129.8 & 8.9 & 120.9 \\
\hline 2012 & 120.6 & 111.5 & 9.1 & 102.4 \\
\hline 2013 & 59 & 49.4 & 9.6 & 39.8 \\
\hline
\end{tabular}

Source: Official statistics published by the Belarusian Embassy to Tehran and National Statistical Committee of the Republic of Belarus.

Trade volumes remained loosely linked to political cooperation, particularly with Iranian exports to Belarus taking time to reach a reasonably large volume. This demonstrates not only differences in the level of industrial development of the countries, but also underscores the differences in national economic management. The Belarusian government could order its state-owned or state-controlled industrial firms to launch business activities in Iran. The Iranian government lacks the ability to directly bring national business to cooperate with Belarus. The Iranian state, with its factions of elites, lacked a consistent policy of economic cooperation with Belarus. In addition, Iran and Belarus are new partners and it takes time before trade links can become well-developed.

Bilateral relations in this period included some episodes of military and militarytechnical cooperation, although the evidence is scarce. Sometimes experts merely speculate on dubious information. In January 2007 Belarusian Defence Minister Malcaŭ paid a two-day visit to Iran, signing a memorandum of understanding on defence issues (RIA Novosti 2007). In July 2007, Iranian Defence Minister Mustafa Muhammad Najar visited Belarus (Press TV 2007). 
By the late 2000s Belarus already switched from selling Soviet arms to more sophisticated forms of international defence cooperation.

In particular, in 2010, the Iranian military Malek Ashtar University signed an agreement on joint command-and-control $\mathrm{PhD}$ courses with an unnamed Belarusian university (FARS 2010). In 2008, the Iranian Communication and Information Technology Minister Muhammad Suleimani negotiated with Belarusian officials to establish cooperation in space communication which might have a military application (FARS 2008). Moreover, in 2013 Iranian state TV broadcast a documentary convincingly claiming that Tehran had acquired new Belarusian electronic warfare equipment, without specifying when and under which circumstances (YouTube 2013).

\section{Decline, 2009-2013}

Relations declined abruptly at the beginning of 2010. Official visits became very rare. If in 2006-2010 Belarus and Iran exchanged up to ten official visits of (at least some) significant value, then in 2011-2012 there were only three important visits (yearly) (Bohdan 2012). The largest projects launched under the Ahmadinejad presidency (Iranian car production in Belarus and Belarusian oil extraction in Iran) had failed by that time. In the former case, the Belarusian government apparently did not care about sales of Iranian cars and the Iranian side did not care to replace Iranian components in cars with Belarus-manufactured ones.

In the latter case, the reasons for halting the project were not so clear. In August 2011, the Belarusian oil company, Belorusneft, declared that it had stopped working in Iran. The Iranian side accused the Belarusians of failing to achieve the agreed upon extraction levels. Some Belarusian non-governmental media said that Belorusneft had given up cooperating with Tehran because of sanctions placed on the company by the United States in March 2011. Irrespective of which version is right, the Belarusian government evidently was not willing to invest much into a project which was becoming a liability and attracting the unwanted attention of Washington.

The only partially successful large-scale project between Belarus and Iran is related to building the logistical centre 'Pryliessie' near Minsk. The Iranian private company 'Kayson' (connected with factions of the Iranian ruling establishment affiliated to Ahmadinejad) implemented this project. Moreover, the project was delayed for years and is still far from completion. The first component of the project should have been finished by 2011, and the second by 2013 (TUT.by 2013). 
The collapse of Belarus-Iranian relations did not attract much attention within the Belarusian government, elites or media. Both internal and external factors led to the disruption of bilateral relations between the two nations. Thus, the Iranian government under Ahmadinejad became increasingly weak after large segments of the Iranian political establishment became estranged from his radical programs. The election of a new parliament critical of Ahmadinejad and mass protests after the 2009 presidential elections in Iran did not allow him to act freely abroad, depriving him of structural conditions for successful international cooperation.

But, similar problems had also undermined the foreign policy of Ahmadinejad's predecessor (President Khatami). However, this had failed to disrupt BelarusIranian relations during his presidency. Therefore, the main reason for the collapse of Belarus-Iranian relations in the early 2010s is related to new changes in the global international structure and the place of both countries within this structure. Iran faced more and more sanctions which (in contrast to 1990s) were not only American businesses, but were supported by European nations too. Moreover, since 2009 the prospect of an American military strike became a real possibility.

This potential Western (primarily with the United States and Israeli) military confrontation with Tehran that may occur has made cooperation with Iran an even more risky undertaking. Belarus can count on Russian covering their backs far less now. Russia had to renounce in 2009 and 2010 deals with some regimes opposing the West (Iran and Libya, respectively) in the military field in response to Western wishes. Minsk had to begin contemplating the possibility of being on the wrong end of a potential conflict and incurring grave political consequences for its continued challenges to Western countries, primarily the United States and Israel. Belarus' foreign policy in the Middle East has always been cautious, especially when working with Middle Eastern governments who engage in open confrontation with the West. The only exception remains Saddam's Iraq, but in that case Minsk could count on Russia defending Belarus from possible Western criticism.

Minsk was promised rewards for renouncing its cooperation with Iran, as well as inducements for Belarus to change its relationship with Syria. Belarusian cooperation with both countries has been targeted in parallel by both Western and Middle Eastern opponents of Tehran and Damascus. It was these very tactics that opponents of the Iranian regime used in dissuading Moscow from continuing much of its work with Tehran and Damascus. The cables revealed by Wikileaks confirm that Israel and rich Arab monarchies worked steadily to turn Moscow away from Iran. In one cable, United States diplomats openly state that in order to get Russian support on sharper actions against Iran, a coordinated strategy by United States allies (including Israel and Saudi Arabia) was required (Der Spiegel 2010). This 
was achieved not only by putting pressure on the Kremlin, but through an approach that would also benefit Moscow. For instance, the Saudis negotiated with the Kremlin on buying significant quantities of Russian weapons.

In order to turn Minsk away from Tehran, the Arab monarchies' and Israel worked effectively if not together then concurrently. Since the late 2000s, Belarus has secured some minor contracts with the Persian Gulf Arab monarchies, first of all with Qatar, then Oman and the United Arab Emirates. They have all since the late 2000s been supportive of Western pressure and even military action against Iran. Respective Arab nations and Belarus have exchanged a series of visits since 2009. Arab monarchies and the Belarusian government apparently discussed widescale projects (like 'Qatari Island in Europe'). Lukašenka publicly boasted of Minsk's plans. Yet in the course of time very little has materialised.

Belarus maintains good relations with Israel. Israeli Deputy Prime Minister and Foreign Minister Avigdor Liberman raised the issue of Belarusian cooperation with Iran at negotiations in Minsk stating that 'Iran is threatening stability in the world. Militants operating in our country are trained in Iran. It is our position and I believe that we can reach a mutual understanding on this issue as well'. This forced the Iranian ambassador in Belarus to protest (Naviny.by 2009). According to the Belarusian Foreign Ministry:

the head of the Belarusian foreign ministry informed his Israeli counterpart that our country is developing fruitful relations with Iran. (...) He emphasised that Belarus-Iranian cooperation has a peaceful character and is not aimed against third countries (2009).

Turkey has also got involved with Belarus (although much later from others in its region). Previously minimal Turkish-Belarusian contacts considerably increased in the early 2010s. In 2013, Turkey made an unprecedented move. It sent its Foreign Minister (Ahmet Davutoğlu), the architect of a proactive Turkish policy in the Middle East, to Minsk - under the pretext of signing an ordinary agreement - to discuss the situation in the Middle East. That took place amidst the crisis surrounding Syria as Iran openly involved itself in shoring up the acting Syrian government and Belarus was repeatedly accused of providing Syrian government forces with military equipment.

The Belarusian policy of reducing the frequency and level of contacts with Iran is not an isolated case of one country distancing itself from Tehran under a series of specific circumstances. Belarus has merely followed a global trend (confirming structural realist assumptions) perpetuated by countries that follow the foreign policy of the United States. These countries have increasingly reduced contact with Iran in the course of the global shift from a bipolar, to post-bipolar and unipolar 
world.

If in the 1990s the United States failed to convince or compel other countries to join in on its sanctions (including European states close to Washington), then in the 2000s American sanctions effectively became multilateral. More and more nations joined America in isolating Iran. By the late 2000s, even Moscow effectively supported these sanctions. However, Russia veiled this support of Washington's policy by reinterpreting UN resolutions very broadly, in contrast to American understanding of UN restrictions on trade with Iran. ${ }^{3}$

Belarusian policy towards states opposing the West was possible due to Russian cover for Belarusian foreign activities. This cover, however, was gradually weakened as Russia lost the remnants of its power. Russian diplomats still tell Western countries not to encroach on post-Soviet nations 'you have already woken up the Belarusian wisent, now you are going to wake up the Russian bear, as well', warned the Russian representative in the OSCE (Naša Niva 2011) explaining that Russians would defend 'our Byelorussia, Uzbekistan and Turkmenistan as they are our allies’ from Western criticism (Naša Niva 2011).

But, this concerns Russia's immediate neighbourhood. Elsewhere, Moscow's influence has diminished. Russia by the late 2000s did not dare develop cooperation with Iran itself as, for example, it had done with another fierce opponent of the United States - Iraq only a decade prior. Moreover, Minsk had by the late 2000s become more interested in gaining more independence from Moscow by working with the EU, China and developing countries. The Russian government, however, was dissatisfied with Belarus' aspirations. The Kremlin attempted to counteract Belarusian attempts to develop relations with developing nations. A case in point is Russia's active political and publicity campaigns launched to disrupt BelarusVenezuelan cooperation in the oil sector.

This means that Minsk has little choice but to gradually accept the United States' demands on all countries in the world to minimise contacts with Tehran. This change was essentially driven by the emergence of a unipolar world, although it was nevertheless delayed for years and ultimately modified by the peculiar circumstances that surround Belarusian foreign relations.

\section{Relative Losses: Belarusian Relations with the West}

Working with Iran, Belarus has not only achieved relative gains in relations with other countries, but has suffered relative losses with America due to its relationship

3 The most illustrative case of this is the ban put by Russian president Medvedev on the selling surface-to-air missile systems S-300 to Iran. The ban referred to UN Security Council Resolution 1929 which, however, can only implicitly be interpreted as including such weapons. 
with Iran. American sanctions against Belarusian companies reduced the attractiveness of cooperation with Iran for the Belarusian government. As early as September 2004, the United States sanctioned the Belarusian company Belzneshpramservis for allegedly selling equipment and technologies that could help construct cruise and ballistic missiles (Belapan 2004). In July 2010, American sanctions occurred against Beltekheksport for its alleged cooperation with Iran, Syria and North Korea. In May 2011 sanctions were commenced against BelOMO too.

In January 2012, American sanctions were introduced against the Belarusian bank Torgovyj Kapital, forcing Belarus' National Bank to recall the licence of the bank for some operations (Nacyjonalnyj Bank 2012). In February 2013, the United States State Department introduced sanctions against two Belarusian enterprises, TM Services Limited and Republican Scientific Industrial Unitary Enterprise DB Radar (Eastbook 2013). Just before that date, Iranian TV demonstrated using a Belarusian radar used to down an American drone (Belarus Digest 2013).

Belarusian officials stated that American sanctions were efficient in stopping some important deals between Minsk and Tehran. Thus, in October 2011, Nadzieja Jermakova (chairwoman of the Belarusian National Bank) said that negotiations over a \$400 million loan, which Belarus hoped to get from Tehran, was suspended, because of United States sanctions against the Iranian Central Bank (AEB.by 2013; Euroradio 2012). As Belarus had minimised cooperation with Iran, in May 2013, the United States removed sanctions against Beltekheksport and BelOMO (Naša Niva 2013). However, given the timing (before presidential elections in Iran) and the fact that Washington also removed sanctions against other Iranian and foreign enterprises, removal of these sanctions might be more a gesture towards factions of the Iranian establishment who supported rapprochement with the US.

The negative consequences of cooperation for Belarus with Iran were, however, not limited to sanctions. The Belarusian state itself risked becoming classified as a threat to international security. The Jerusalem Post in 2008 and 2009 accused Belarus of selling S-300 surface-to-air missile systems to Iran, and in July 2010 a similar accusation was articulated already by the Associated Press (Naša Niva 2010). In reality a deal of this nature would not violate UN sanctions, as the weapon system was not on the list of equipment banned for sale to Iran. Still, this detail was not mentioned. However, even some Belarusian experts claimed that such a deal would violate of UN sanctions (Fyodorov 2009).

The Belarusian opposition has widely discussed possible deals between Minsk and Tehran. Such deals would, of course, attract more Western attention to the cause of regime change in Belarus, especially if the West were to conclude that Minsk was an international security threat. So far, few Western analysts and scholars pay attention to Belarus-Iranian relations at all and only some minor publications 
mention in passim their defence-related aspects (for example, Katzman 2010, 16).

\section{Discussion: What Neorealism Says about Belarus-Iranian Relations and the Timing of Cooperation}

Before the end of the Cold War Belarus - then a Soviet Union republic effectively did not exist as an independent nation while Iran opposed both the United States and Soviet Union. Still, the logic of the bipolar world, when every major international interaction was considered in terms of confrontation between two superpowers, allowed Tehran to avoid harsher treatment from Washington, after Iran launched its large-scale revisionist foreign policy in 1980s. The United States had to restrain itself from punishing the Iranian government out of fear they could push Iran towards the Soviet Union. This fear was somewhat exaggerated. Iran followed an ideologically-driven foreign policy, approaching in a rather limited manner (in comparison to, say, Soviet ties with Iraq or Syria) the Soviet Union only in 1989 when Soviet-US relations were at their best.

The unipolar world that emerged in the early 1990s created a completely new situation for Belarus and Iran. Belarus suddenly found itself independent, yet the West increasingly lost interest in it after Minsk gave up its nuclear arms (Kravchenko 2006a). Eastern Europe transformed from a major potential battlefield of the Cold War into a socially and politically problematic, strategically marginal buffer zone between two partners, the West and Russia.

Belarus became marginalised in geopolitical terms. Its government was poorly prepared for running an independent country, having problems with attracting any viable western partners. A case in point was Belarus' relations with America. According to Alexander Tikhomirov, in the early 1990s, 'political dialogue was primarily on the issue of nuclear arms removal from Belarusian territory...United States politicians [...] tended to consider Belarusian issues in the context of ... USRussian relations' $(2012,70)$. Although Minsk eventually turned to Moscow for survival, from its very inception the Belarusian state looked for contacts in the developing world.

Since the early 1990s, Iran has not been able to exploit American fears of the Soviets potentially strengthening their ties and had to deal with ever more proactive policy from the United States as the world's sole superpower. Discussing the notion of great power, Waltz $(1964,888)$, contends that it cannot 'exert a positive control everywhere in the world' but 'has global interests which it can care for unaided'. ${ }^{4}$ Thus, there were places in the world that were not under American control (in

\footnotetext{
${ }^{4}$ Certainly, this text of Waltz refers to bipolar world, but there are no plausible grounds to suppose it
} being otherwise in post-bipolar or unipolar world order. 
particular in post-Soviet space). The former Soviet Union presented the Iranian government with numerous opportunities for economic cooperation. Even more important to Iran was its own military's modernisation and the United States had (especially in the early 1990s) more pressing issues in the post-Soviet space to worry about than Iran's procurement of conventional weapons.

By the mid-1990s this, however, had all changed. Washington paid ever more attention to Iran's activities in the former Soviet Union. In 1995 the Americans got Moscow to sign the Gore-Chernomyrdin memorandum (1995), on the complete halt of all Russian arms transfers to Iran. This was a serious blow to the Iranian national security apparatus. At this time the Iranian government faced troubles with its Western-made weapons and equipment, which could not be maintained after its break with the West. Of course, before the 1995 memorandum was signed Tehran had time to get considerable quantities of (post)Soviet weapons and equipment to rearm after prolonged fighting with Iraq. Yet Iranian military modernisation was still far from complete.

The end of the Cold War for Iran actually meant the beginning of a new round of isolation of Iran by the United States and its inclusion into the 'Axis of Evil'. Its contacts with other countries were often interpreted by Western analysts, especially United States officials and the media, as a potentially dangerous attempt to break out of its isolation. It was assumed that the Iranian regime would try to acquire defence-related goods and technologies. The comments made by the West about Lukašenka's visit to Tehran in 1998 are just one example (Gertz 1998).

\section{Rationale for Cooperation}

Hence, one must gauge the importance of considering the whole international constellation and not only cooperating states for every instance of cooperation. It is this constellation which explains the motives for any kind of cooperation. As long as Belarus and Iran consider one another capable of promoting each other's shared interests, their governments will support cooperation. For Iran, cooperation with Belarus has been an additional source of equipment and technologies in Iran's confrontation with adversaries, especially Iraq (in the 1990s) and the USA (throughout this period of time, i.e., in 1990s-2010s).

For Belarus, the situation was more dynamic. Neorealist logic does not preclude us from taking into account specific notions of vital national interests and factors endangering national security held by the Belarusian leadership. Despite its loud rhetoric, the Belarusian government has hardly contemplated the possibility of a serious and direct military threat to its existence (as evidenced by low 
levels of defence spending). On the contrary, its notions of what the vital interests of the state constitute and what threatens the state's existence stem from late Soviet times. Facing financial difficulties, the Soviet leadership adopted a doctrine of ' $\mathrm{New}$ Political Thinking'. This, to a considerable degree, dismissed the main military components in its security policy in favour of internal stability. In circumstances of socioeconomic crisis, the government has to ensure stability by seeking international cooperation to find money and material goods needed by citizens.

Therefore, during certain periods Minsk has considered Iran as a potential source of money enabling it to reinvigorate the state and the economy (in the late 1990s and early 2000s). At other times Minsk believed that Tehran would help the Belarusian regime diversify its political and economic relations and strategically strengthen Belarus' position, for instance, by providing Belarus with a new source of oil or investments and markets needed by Belarusian industry.

There were, nevertheless, times when Minsk believed that relative losses were heavier than gains from its relationship with Tehran. It even at times renounced cooperative projects. The effective renouncement of military contacts and militaryrelated projects since the late 2000s and a general absence of contact with Iran since 2010 illustrate this thinking. Back then, after the sanctions against Belarusian defence industry firms for alleged deals with Iran, the Belarusian leadership faced the prospect of being regarded by Western nations (especially the United States and Israel), as a threat to international security because of Minsk's Iranian connection. Moreover, some part of the Belarusian political establishment might have demonstrated their wish to find more pragmatic arrangement with the West by changing political line on Iran.

The volatile international environment for Belarus pushed the Belarusian government into minimising its contact with Iran. This was due to growing Western sensitivity on contacts with Iran after the Iranian nuclear crisis became an issue in the late 2000s and Russia's increasingly antagonistic position on Iran. In March 2009, United States Secretary of State Hillary Clinton and Russian Foreign Minister Sergey Lavrov pushed a symbolical 'reset' button. President Dmitry Medvedev and President Barack Obama at the 2009 G20 summit in London released a joint statement proclaiming a 'fresh start' in bilateral relations. Within the statement both Russia and America urged Iran to abandon its nuclear program and permit international inspectors into the country (Cooper 2009). On 22 September 2010, Russian President Medvedev banned the sale of S-300 long range surface-to-air missile systems and other weapons to Iran.

In those circumstances, Minsk's policies of cooperation with Tehran ran counter to the political stance of not only of the West but also of its closest ally, 
Russia. On the one hand, the risk of international repercussions became very clear. On the other hand, Belarus only had some vague opportunities for cooperation with Tehran. Such an international constellation left no choice for the Belarusian government but to restrict contacts with Iran unless Belarus was willing to openly challenge the global system. It was not willing to do so, especially given its 20082010 attempts to improve relations with the West.

Thus, the ruling establishment in Belarus hardly considered the Iranian regime a threat, and vice versa. The Iranian ruling elite did not regard Belarus as a danger. The opposition in both countries has sometimes articulated other visions, yet in both cases they have remained marginal as far as foreign policy decision-making is concerned.

Threats differ. For Belarus the most acute problem is its vulnerability to Western and Russian pressure, resulting in the necessity to balance these pressures and play both sides against each other while trying to find a 'third force'. The Belarusian government cares about this much more than about the theoretical possibility of an Iranian threat to international community which (according to some interpretations) can in the very distant future threaten Belarus as well. Moreover, Gilpin emphasised that the international system 'stimulates, and may compel, a state to increase its power; at the least it necessitates that the prudent state prevents relative increases in the power of competitor states' (1981, 87-88). This means that a state does not need to compare its own capacities with friendly states. Instead, it should compare itself to rivals. For Iran this means that it has to compare its potential power and capabilities with those of the United States, as well as those of some other countries (especially Arab nations). Belarus has to strive for something less, such as finding means to fend off Western and Russian pressure. Iran and Belarus have no reason, then, to compare their own capabilities, as no competition exists between Minsk and Tehran.

A state must be concerned with its own position not only in the entire international system, but also in one or more of its various components (subsystems). For instance, Belarus has to care about its own standing in (and towards) the three, (partly overlapping regions, or subsystems) of vital importance to it individually; Eastern Europe, the EU and the former Soviet Union. On the other hand, Iran has to care about its global stature, and the Islamic world, the Middle East, the Persian Gulf, Central Asia and the Caucasus.

\section{Was There an Alliance between Belarus and Iran?}

In the period under consideration (1990s-2010s), one example of factors leading to the establishment of balancing alliances is America's global ambitions. These 
ambitions have severely threatened Iran's regional ambitions, changing (mostly in a restrictive manner), international options for Belarus. For Belarus, another example of regional domination requiring counterbalancing involves Russian dominance in Eastern Europe. Minsk tries to resist it, resorting to rapprochement with the EU and China and conducting an active foreign policy in the developing world, in particular with Iran.

Meanwhile, Belarusian foreign policy includes more aspects than merely counterbalancing Western and Russian pressure. It is feasible to imagine Belarus seeking alliances with developing nations (like Venezuela) and/or China against the West and Russia. Despite the evident inequality of these options, Venezuelan, Chinese or Iranian connections can indeed provide Minsk with some leverage in dealing with its two major international partners - the EU and Russia.

It means that cooperation between Belarus and Iran aimed at obtaining relative gains in relation to third countries is a kind of balancing alliance. The model of the balancing alliance itself explains the fruitfulness or futility of cooperation initiatives. Thus, when both states in bilateral relations aspire to balance third countries through this bilateral cooperation, only then can the cooperation lead to tangible results.

Balancing alliances are therefore a second concept by which cooperation between Belarus and Iran can be analysed. Tehran in the 1990s-2010s was interested in every (and any) alliance, which enabled it to counterbalance American influence in its own neighbourhood (the Persian Gulf, the Caucasus and Central Asia). The same is true for Belarus, which attempted to resist pressure from the EU and Russia.

This strategy had little chance for success. Belarus limited its confrontation with America to rhetoric and symbolic gestures without taking serious political measures that would damage its relationship with Washington. Iran, on the other hand, did not embark on working against Russian interests even in regions where Iran had advantages, such as common cultural and historical heritage or geographical proximity, or when the states in question had an objectively higher strategic value for Tehran. Amir Mohammad Haji-Yousefi analyses the foreign policy of Iran using neorealist concepts:

The foreign policy of the Islamic Republic of Iran in Central Asia and the Caucasus has been shaped by the perception of...necessity to strategically cooperate with Russia, in confrontation with America... it resorted to the conventional policy of alliance and resulting partial balancing..., i.e., cooperation with Russia in order to confront America. It was because of this necessity that the policy of the Islamic Republic of Iran in Central Asia and the Caucasus - contrary to its policy in Persian Gulf in 1980s - was based on pragmatism ['amalgaro] and a conservative course (1381, 1025-26). 
In Belarus, Tehran worked in an unknown country and restrained its policies. Of course, some Iranian officials in the late 2000s informally described Belarus as one of 'Iran's windows to the world' which should be kept open in case sanctions were strengthened. They stated that Belarus was one of the few pillars on which Iran could rely (alongside Cuba, Venezuela and Syria) (Hosseini 2008). However, this position has remained marginal in the Iranian regime, even under the presidency of Ahmadinejad. Tehran has strived to build a balancing alliance with Moscow, not Minsk.

If the refined concept of relative gains in a neorealist international cooperation model explains why Minsk and Tehran cooperated at all, the concept of the balancing alliance explains further why this cooperation remained limited and unstable. The alliance between Belarus and Iran never gained solid ground and both nations developed their relations on a more ad hoc basis.

\section{Troublemakers Growing Stronger?}

Foreign policy expands as the state grows stronger and more ambitious. That was true for Belarus and Tehran as well. Despite the apparent internal and external problems for both nations in the 1990s and 2000s the capacities of both states increased and the ruling elites set new targets to achieve.

The initiative to establish relations between the two countries belonged to Iran. Its activity towards the former Soviet republic came on the heels of the new status of Iran in the early 1990s. For Iran, the end of the war with Iraq, political changes and renewal of the leadership in the late 1980s gave rise to a new age (known as the 'Reconstruction Epoch') when under President Rafsanjani the country accelerated its economic development. Thus, the Iranian regime could afford to pursue larger security and welfare goals abroad especially since the early 1990s.

The dual processes of economic development and military modernisation since the late 1980s led to a certain revisionism on the part of the Iranian government which was relatively successful in increasing its regional influence in the 1990s and 2000s.

According to Friedberg:

fast-rising powers are almost invariably troublemakers... Emerging powers seek to change, and in some cases to overthrow, the status quo and to establish new arrangements that more accurately reflect their own conception of their place in the world $(1996,13)$.

So many Western commentators (like Vali Nasr) perceived shifts in the neighbourhood of Iran in the 2000s, like the establishment of a Shiite-dominated government in Iraq and the successes of Hezbollah and Hamas in the 2000s (Berman 
2005). Iran has had in the last couple of decades an inherent aspiration to change its security environment in accordance with its own strengthened position. These aspirations shape many aspects of Iranian foreign policy and did not emerge under the Islamic Republic. Rather they already existed under the pre-1979 monarchy, which also aimed to review the existing constellation of world powers.

Similar developments occurred in Belarus. The Belarusian state surmounted the economic and political difficulties of the early 1990s, entering an authoritarian phase of political evolution by the end of the decade. Using enormous Russian subsidies and its resources while consolidating its state apparatus, Lukašenka's government could afford to give more attention to creating a favourable environment for itself by launching a diversified foreign policy. Opportunities for improving its position increased further in the 2000 s.

\section{Role of Domestic Factors}

Domestic factors clearly have rendered some influence on cooperation between Iran and (post)Soviet nations. As Tehran gained a growing understanding of the post-Soviet through developing networks of Iranian diplomatic and trade missions and business contacts (mediated in Belarus by reconciled Iranian Communist political refugees from the 1980s), Belarus-Iranian relations advanced.

The end of the war with Iraq and revival of the Iranian economy under Rafsanjani and Khatami led to increases in the amount of resources available to the Iranian government. This resulted in bigger security ambitions and aims and achievements facilitated by some other factors, like the collapse of the Soviet Union on its northern borders.

For its part, the Belarusian government could better pursue cooperation with Iran after it built up its own system of political research and intelligence in the form of analytical centres and diplomatic missions in Iran and its neighbourhood. For Belarus, the 1990s was a time when both state institutions and Belarusian national identity were formed. Therefore, its relations with the developing world (existent on an ad hoc basis since 1992) became relatively stable and consistent only in the late 1990s and early 2000s. This general pattern can be assigned to Belarus-Iranian relations too.

In the case of Iran, post-Soviet Belarus and the United States, there are many distinctive ideologies used by the respective governments to justify their actions. Iranian foreign policy in the 1990s-2010s articulated Islamic, Shia and Thirdworldism rhetoric. However, it widely displayed pragmatic traits through effective cooperation with the United States in the Gulf War (1990-1991) and the American invasion of Iraq (2003), as well as the United States invasion of 
Afghanistan in 2001

The Islamic ideology of Iran and conservative statist ideology of Belarus display some similarities in their views on the state and its relation to society. Yet, they radically differ in their fundamental world view. Belarus-Iranian cooperation was restrained by the United States policy towards Iran buoyed by America's promotion of the ideals of liberal democracy and human rights. Carr, however, warns that 'in the international order, the role of power is greater and that of morality less' (2001, 151). Indeed, the dynamics of Belarus-Iranian relations displays no clear link to the ideological preference of any of the three states. The Iranian and American ideological position remained essentially unchanged throughout these years and Belarus changed its vague ideology in a minimal way.

\section{Conclusion}

The neorealist approach within international relations and international politics explains Belarusian foreign policy towards Iran, which has constituted an important direction of Belarusian foreign policy since the late 1990s. It also explains Iranian policy towards Belarus, which was never of much importance for Tehran, where the regime pursued limited goals in dealing with Minsk.

Since relations between Belarus and Iran formally began in 1993 there have been a series of quantitative and qualitative changes. The general contours of development were shaped by the gradual establishment of unipolar world, with the United States as the sole superpower trying to isolate the Iranian regime. However, this process lasted many years for all the world's countries. Belarus won even more time to enhance its deals with Iran despite Western opposition thanks to its alliance with Russia, which supported Belarusian foreign policy in many directions, including in the Middle Eastern one.

By the late 2000s, Russia had ever less opportunities to provide this cover. Moreover, it was far less motivated to do that as Minsk strove for more independence from Moscow. In these circumstances, political contacts between Belarus and Iran rapidly decreased.

The Belarusian opposition has always criticised contacts with Iran, frequently implying that rapprochement between Minsk and Tehran stemmed from the ideological anti-American affinity of the regimes. The Middle Eastern policy of the Belarusian regime, however, provides just one more illustration of the regime's generally opportunistic nature. This may explain the rapid decline of relations between Belarus and Iran, once relative gains from cooperation disappeared.

The pattern of relations with Iran shows the flexibility of the current Belarusian leadership which seeks to benefit itself, rather than challenge the existing 
international order in any serious way. Moreover, in the long run it tried to avoid trouble with America and the West in general. Despite all its efforts to do the contrary, Minsk has followed global trends, accepting American dominance in this sphere and probably not only in its Iranian policy (another obvious example is Belarusian silent cooperation with NATO).

Neorealist theory has proven to be successful in explaining Belarusian relations with Iran. Given the lack of any well-founded ideology displayed by the current Belarusian leadership, it is logical to think that its actions are driven, first of all, by an opportunistic/pragmatic drive for power. The neorealist paradigm can provide a new, more profound understanding of Belarusian external relations with other regions and countries as well.

\section{References}

AEB.by, 2012. 'Belarus - Irak - Iran: peremennyi uspekh', 17 July <http:// www.aeb.by/news/belarus-irak-iran-peremennyi-uspekh $>$ [accessed 2 January 2013].

Arjomand, Said Amir, 2009. After Khomeini: Iran Under His Successors, Oxford: Oxford University Press.

Azghandi, Ali-Reza, 1388. Siasat-e khareji-ye jomhuri-ye eslami-ye iran, Chap-e panjam, Tehran: Nashr-e ghoms.

Belapan, 2011. 'Makey prokommentiroval mnenie Lukashenko o stat'e Putina v "Izvestiyakh", 23 October < http://news.tut.by/politics/255567.html>. [accessed 14 November 2013].

Berman, Ilan, 2005. Tehran Rising: Iran's Challenge to the United States, New York, Toronto: Rowman and Littlefield Publishers, Inc.

Bohdan, Siarhei, 2013. 'Arms Trade Charges Against Belarus: Speculations and Facts', Belarus Digest, 13 March < http://belarusdigest.com/story/arms-tradecharges-against-belarus-speculations-and-facts-13320 $>$ [accessed 2 January 2013].

— 2012. 'Perhaps we will abandon the Iranians for the benefit of the Chinese» (C). A case study on the Belarus-Iran relations in 1993-2012', Belarusian Institute for Strategic Studies, 18 November <http://www.belinstitute.eu/en/ node/673> [accessed 18 November 2012].

Bojarczyk, Bartosz, 2009. 'Stosunki białorusko-irańskie', in Ireneusz Topolski (ed.), Białoruś w stosunkach międzynarodowych, Lublin: Wydawnictwo Uniwersytetu Marii Curie-Skłodowskiej. 
Brazovskaya, V.L., (ed.), 1996. Tolko narod vprave reshat'svoiu sud'bu! Materialy Vsebelorusskogo sobrania 19-20 oktiabra 1996 g., Minsk: Belorusskiy dom pechati.

Carr, H. Edward, 2001. The Twenty Years' Crisis: An Introduction to the Study of International Relations, New York: Palgrave.

Cooper, Helene, 2009. 'Promises of "Fresh Start" for U.S.-Russia Relations', New York Times, 1 April <http://www.nytimes.com/2009/04/02/world/ europe/02arms.html?_r=1\&hp $>$ [accessed 1 April 2009].

Czachor, Rafa1, 2011. Polityka zagraniczna Republiki Białoruś w latach 19912011. Studium politologiczne, Polkowice: Wydawnictwo Dolnośląskiej Wyższej Szkoły Przedsiębiorczości i Techniki w Polkowicach.

Dehghani, Firouzabadi and Jalal Seyed, 1389. Siasat khareji-ye jomhuri-ye eslami-ye iran, Chap-e sewwam, Tehran: Sazman-e mottale'e wa tadwin-e kotob-e olum-e ensani-ye daneshgah-ha.

Der Spiegel, 2010. 'Die heimliche Allianz', 48, 29 November <http://www. spiegel.de/spiegel/print/d-75376496.html> [accessed 30 November 2010].

Eastbook.eu, 2013. 'Novye sankcii SShA protiv Belarusi', 13 February $<$ http:// eastbook.eu/ru/2013/02/topic-ru/politics-ru/novye-sankcii-protiv-belarusi-usa/> [accessed 13 February 2013].

Euroradio, 2012. 'Sankcii ZShA pieraškodzili pieramovam pra iranski kredyt dlia Belarusi', 29 June <http://euroradio.fm/report/sanktsyi-zsha-perashkodziliperamovam-pra-iranski-kredyt-dlya-belarusi-111533> [accessed 29 June 2012].

FARS News Agency, 2005. 'Parliament Speaker upon his Arrival from the Central Asian Republics: Belarusian President to Visit Iran Next June', 17 December <http://english.farsnews.com/newstext.php?nn=8409260538>. [accessed 6 June 2010].

- 2008. 'Iran, Belarus to Cooperate in Space Communication Programs', 23 October $2008<$ http://english.farsnews.com/newstext.php?nn=8708020635>. [accessed 6 June 2010].

— 2010. 'Iran, Belarus to Hold Joint Command-and-Control PhD Courses', 24 May <http://english.farsnews.com/newstext.php?nn=8903031716> [accessed 6 June 2010].

Feduta, Alexandr, 2005. Aleksandr Lukashenko: Politicheskaia biografiia, Moscow: Referendum.

Friedberg, Aaron, L., 1988. The Weary Titan: Britain and the Experience of Relative Decline, 1895-1905, Princeton: Princeton University Press. 
—, 1996. 'Warring States: Theoretical Models of Asia Pacific Security', Harvard International Review, 18 (Spring).

Fyodorov, Andrei, 2009. 'Belarus - Third World: Nothing But Hope So Far', in Belarusian Yearbook - 2008. A Survey and Analysis of Developments in the Republic of Belarus, Minsk: Belarusian Institute of Strategic Studies, Belarus Public Policy Fund.

Gilpin, Robert, 1981. War and Change in World Politics, Cambridge: Cambridge University Press.

Haji Yousefi, Amir Mohammad, 1381. 'Nazari-ye Waltz wa siasat-e kharejiye iran: Mottale-ye moghayeseyi-ye douron-e jang-e sard wa pasajang-e sard', Faslname-ye siasat-e khareji (Nashriye siasi, eghtesadi, farhangi wa hoghughi), Sal-e 16, zemestan.

Hosseini, Abdullah, 2008. Conversation with Iranian Ambassador to Minsk Abdullah Hosseini, November, Minsk.

Hunter, Shireen, 2010. Iran's Foreign Policy in the Post-Soviet Era. Resisting the New International Order, Santa Barbara, CA: Praeger/ABC-CLIO.

Gertz, Bill, 1998. 'Belarus, Iran Plan Weapons-Trade Pact,' The Washington Times, 17 February.

Grieco, Joseph M., 1988. 'Anarchy and the limits of cooperation: a realist critique of the newest liberal institutionalism', International Organisation, 42, 3 (Summer).

Katzman, Kenneth, 2010. 'Iran: U.S. Concerns and Policy Responses', DIANE Publishing.

Kebich, Vyacheslav and I.N. Osinskii (ed.) 2008. 'Iskushenie vlastiu: iz zhizni premer-ministra', Minsk: Paradoks.

Kommersant, 1995. 'Voenno-tekhnicheskie sviazi Belorussii i Irana. Vmesto "starshogo brata" opuzhe Iranu prodast' "mladshii", 132, 850, 18 July.

Kravchenko, Pyotr, 2006a. Belarus' na raspuste, ili Pravda o Belovezhskom soglashenii. Zapiski diplomata i politika, Moscow: Vremia.

—, 2006b. 'Belarus' na raspuste', Narodnaja Volia, 6 October.

Leffler, Melvyn P., 1992. A Preponderance of Power: National Security, the Truman Administration, and the Cold War, Stanford, California: Stanford University Press.

Litwak, Robert S., 2000. Rogue States and U.S. Foreign Policy: Containment After the Cold War, Baltimore: The Woodrow Wilson Center Press.

Mearsheimer, John, 2005. 'E.H. Carr vs. Idealism: The Battle Rages On', International Relations, 19, 2 (June), pp. 139-52. 
_ 2011. 'Imperial by Design', The National Interest, 111, January/February.

Naša Niva, 2010. 'Irancy bijucca, a ŭ belarusaŭ čuby traščać', 9 August $<\mathrm{http}$ :// nn.by/?c=ar\&i=41951> [accessed 9 August 2010].

—, 2011. 'Jak Rassiya Lukashenku baronit', 14 July <http:// nn.by/?c=ar\&i=57392> [accessed 14 July 2011].

—, 2013. 'Alesin: Otmena sankcii — dal'novidnyi shag amerikancev, 30 May $<\mathrm{http} / / \mathrm{nn} \cdot \mathrm{by} /$ ?c=ar\&i=110484\&lang=ru> [accessed 30 May 2013].

Nacyjonalnyi Bank, 2012. 'Postanovlenie Natsional'nogo Banka Respubliki Belarus' № 402 ot 3 avgusta 2012g’.

Naviny.by, 2009. 'Belorussko-iranske otnosheniia ne iavliaiutsia ugrozoi dlia drugikh stran, uveriaet iranskii posol', 4 June $<$ http://naviny.by/pda/ material/?type $=$ news\&id $=312417>$ [accessed 9 November 2013].

Official web site of the Ministry of Foreign Affairs of Belarus, 2002. 'Materialy bryfinga pres-sekratara MZS Bielarusi Paŭla Latuški, praviedzenaha dlia pradstaŭnikaŭ SMI 21 sakavika b.g.' <http://www.mfa.gov.by/ru/press/news/2002-03-21-3.html> [accessed 7 July 2010].

-, 2009. 'Otvet press-sekretara MID Belarusi A. Popova na vopros predstavitelei SMI v sviazi s obsuzhdeniem belorussko-iranskikh otnoshenii v khodze vstrechi Ministra inostrannykh del Belarusi S. Martynova i Zamestitel'a Premerministra - Ministra inostrannykh del Izrail'a A, Libermana', 5 June $<$ http://www.mfa. gov.by/ru/press/news/ae70216cdc730f97.html $>$ [accessed 5 June 2010].

Official web site of President of Republic of Belarus, 2013a. 'Aleksandr Lukashenko vstretilsia s vypusnikami voennykh uchebnykh zavedeniy Belarusi i Rossiyi’, 4 July $<$ http://www.president.gov.by/press 145826.html\#doc> [accessed August 2013].

— , 2013b. "Aleksandr Lukashenko dal interviu telekanalu "24 KZ" agenstva "Khabar"”, 1 October <http://www.president.gov.by/press147308.html\#doc> [accessed 29 October 2013].

Otagh bazargani, 1388. 'Akhbar-e otagh bazargani wa sanaye wa keshavarzi wa maadan-e iran', Web-site of the Trade, Industry, Agriculture and Mining Chamber of Iran, 24 Mordad <http://www.iccim.ir/fa/index.php?option=com_content\&view=artic le\&id=5155:1388-05-24-08-49-53\&catid=1:---\&Itemid=81> [accessed 20 December 2010].

Press TV, 2007. 'Iran, Belarus expand defence ties', 5 July $<$ http://edition.presstv. $\mathrm{ir} /$ detail/15489.html $>$ [accessed 23 June 2010].

RIA Novosti, 2007. 'Belarus, Iran sign memorandum of understanding on defense', 24 January <http://en.rian.ru/world/20070124/59644294.html> [accessed 22 June 2010]. 
Schörnig, Niklas, 2006. 'Neorealismus', in Sigfried Schieder und Manuela Spindler (Hrsg.), Theorien der internationalen Beziehungen (2., überarbeitete Auflage), Opladen und Farmington Hills: Verlag Barbara Budrich, pp. 65-92.

Schweller, L. Randall, 1998. Deadly Imbalances: Tripolarity and Hitler's Strategy of World Conquest, New York: Columbia University Press.

Takeyh, Ray, 2009. Guardians of the Revolution: Iran and the World in the Age of the Ayatollahs, New York: Oxford University Press.

Tikhomirov, Alexandr, 2012. 'Razvitie politicheskogo dialoga mezhdu Respublikoi Belarus' i SShA v konce 1991 - nachale 1991 g.', Trudy fakulteta mezhdunarodnykh otnoshenii 2012: nauchnyi sbornik, 3, Minsk: BGU.

TUT.by, 2004. "Belvneshpromservis" otricaet obvineniya Gosdepartamenta SSHA', 1 October <http://news.tut.by/economics/44703.html $>$ [accessed 11 June 2010].

, 2013. 'Iranskii drug Makeya otkryl krupneyshyi skladskoi kompleks pod Minskom', 11 October <http://news.tut.by/economics/369952.html> [accessed 29 October 2013].

Ulakhovich, Vladimir, 2009. Formirovanie osnov vneshnei politiki Respubliki Belarus'(1991-2005), Minsk: Harvest.

United Nations, 2011. 'UN Register of Conventional Arms' <http://unhqappspub-01.un.org/UNODA/UN_REGISTER.nsf $>$ [accessed 5 August 2011].

Waltz, Kenneth, 1964. 'The Stability of a Bipolar World', Daedalus, 93, 3 (Summer).

—, 1979. Theory of International Politics, Reading, Mass.: Addison Wesley.

Wohlforth, William Curti, 1995. 'Realism and the End of the Cold War', in Brown, Michael, E., et. al. (eds.), The Perils of Anarchy: Contemporary Realism and International Security, Cambridge: MIT Press.

Youtube, 2013. Youtube: the $7^{\text {th }}$ second of the video from the First Channel of Iranian TV <http://www.youtube.com/watch? $\mathrm{v}=\mathrm{aByFAwW} 2 \mathrm{Puw} \&$ feature=player detailpage $\# \mathrm{t}=7 \mathrm{~s}>$ [accessed 25 March 2013].

Zakaria, Fareed, 1998. From Wealth to Power: The Unusual Origins of America's World Role, Princeton: Princeton University Press. 